\title{
The climate of Surtsey
}

\author{
GUĐRÚN NÍNA PETERSEN AND TRAUSTI JÓNSSON
}

Icelandic Meteorological Office, Bústaðavegi 9, 108 Reykjavík, Iceland (gnp@vedur.is)

\begin{abstract}
The first meteorological measurement in Surtsey were conducted before the eruption ended in 1967 and since 2009 there have been continous automatic measurements on the island. Here we give the first comprehensive analysis of the climate of Surtsey, based on these observations, and compare it to the climate at the two other stations in the Vestmannaeyjar archipelago, Vestmannaeyjabær and Stórhöfði. Surtsey experiences a relatively mild but windy climate, with monthly mean temperature above freezing during all calendar months and wind speed exceeding $20 \mathrm{~m} / \mathrm{s}$ on average 30 days a year. Precipitation measurements are challenging but show, as expected, the summer months to be the driest and October to be both on average the wettest month but also the most variable month. The measurements show the climate of Surtsey to be similar to the climate of the other two stations in the archipelago with the largest difference in wind speed, where Vestamannaeyjabær is sheltered while at Stórhöfði strong winds are enhanced by the orography.
\end{abstract}

\section{INTRODUCTION}

Surtsey is the southernmost island of the Vestamannaeyjar archipelago as well as the southernmost point of Iceland, approximately $32 \mathrm{~km}$ from the southern coast. It is the second largest island of the archipelago. It rose from the sea floor during an eruption that lasted four years, 1963-1967, and at the end of the eruption the island covered an area of 2.65 $\mathrm{km}^{2}$. However, due to erosion the island has undergone changes and e.g. in 2004 it had an area of $1.41 \mathrm{~km}^{2}$ and a maximum elevation of $155 \mathrm{~m}$ a.s.l. (Baldursson \& Ingadóttir (eds), 2007). The island was in 1965 declared a nature reserve owing to the scientific value of the new island (Surtseyjarfélagið, 2007) and in 2008 it was inscribed to the World Heritage List of UNESCO due to it being a pristine natural laboratory (UNESCO, 2008). Already in April-September 1967 the first routine meteorological measurements were conducted on the island (Sigtryggsson, 1968), with the eruption ongoing until 5 June. Observations were again obtained during April-September 1968, but during both years the measurements had several interruptions and could not be used to obtain direct information on the climate of Surtsey. However, by using the data in comparison to weather observations from Stórhöfði, at the south end of the largest of the Vestamannaeyjar islands Heimaey, Sigtryggsson $(1968,1970)$ could give an overview of the weather conditions during these two period, suggesting that the general climate is similar in both places and the main differences in temperature is due to differences in height above sea level. Automatic measurements over a two-month period in 1996 also strongly indicated the similarity between the weather conditions at the two stations (Baldursson \& Ingadóttir (eds), 2007).

Since May 2009 there have been continuous automatic weather measurements in Surtsey. Here we analyse 10 years of data from Surtsey and compare to data from the other automatic stations in Vestmannaeyjar, namely Stórhöfði and Vestmannaeyjabær. Both stations have been 
operating automatically for over 15 years. In addition, Stórhöfði has a long record of manned observations extending back to 1921 but they were discontinued in 2014. Earlier observations in Vestmannaeyjar extend as far back as 1869. Although the stations are both on Heimaey and the distance between them, as the crow flies, is only $4.1 \mathrm{~km}$ there is a difference in climate, especially wind climate. Stórhöfði is known for high wind speed, due to the station being located at the top of the southernmost tip of Heimaey, at $118 \mathrm{~m}$ a.s.l. On the other hand, the station Vestmannaeyjabær is located within the town on the island, at $40 \mathrm{~m}$ a.s.l. and approximately at the centre of the island, sheltered by low mountains, vegetation and the town itself from the maritime winds. This results in a more pleasant wind climate than at Stórhöfði.

\section{MATERIAL AND METHODS}

The automatic weather station in Surtsey, Station No. 6012 , is located on the south side of the island at 36 $\mathrm{m}$ a.s.l., see Fig. 1. A previous station was located at the top of the island on Austurbunki, at $154 \mathrm{~m}$ a.s.1., in the vicinity of a shelter, see Fig. 1 and Table 1. Some of the earlier measurements were conducted there. See Table 1 for further information on previous and current weather stations in Surtsey.

The station measures all the basic meteorological parameters, i.e. air pressure, temperature, humidity, precipitation, wind speed and wind direction. In addition, solar radiation is measured as well as soil temperature. The measurements are recorded every 10 minutes. Since 13 September 2018 the station is also equipped with a web camera, looking towards the mainland, and photos are saved hourly during daylight hours. Fig. 2 shows a photo of the station and Table 2 contains more detailed information on the equipment at the station. The station is visited every summer for regular maintenance. Sometimes it has been possible to add a visit in the case of

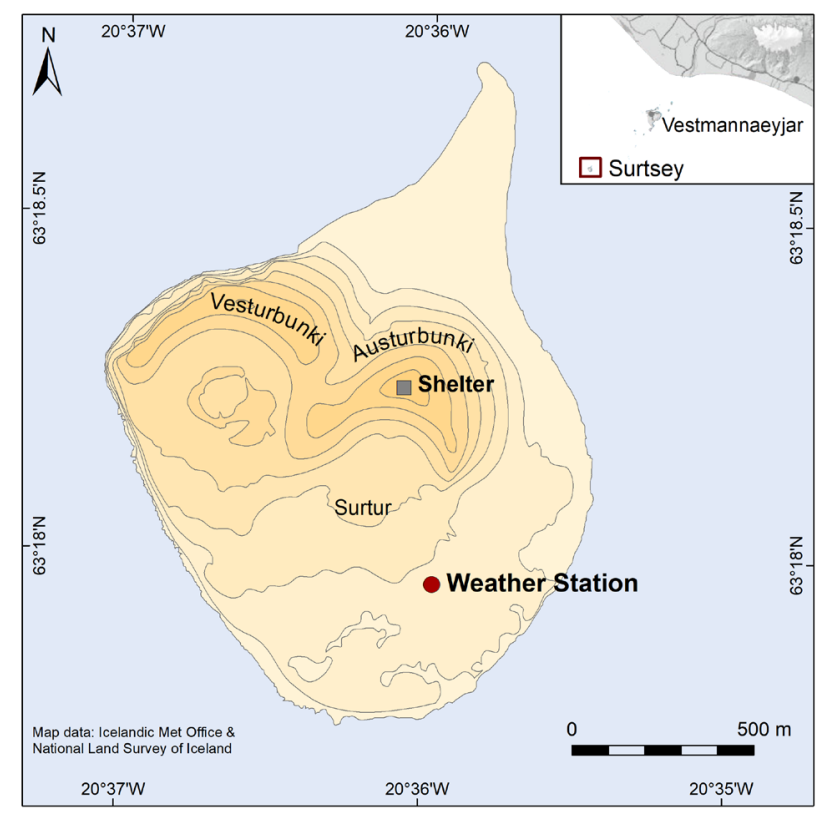

Figure 1. Map of Surtsey showing the location of the current weather station. Some earlier observations were conducted close to the shelter at the top of Austurbunki. The elevation is shown with contours, interval $20 \mathrm{~m}$. Inset map shows location of Surtsey in relation to the Vestmannaeyjar archipelago as well as the southern coast of Iceland.

instrumental failure but often maintenance has had to wait until the next summer visit. As a part of the regular maintenance of the station the temperature and humidity sensor has been replaced five times and the anemometer eight times. The solar radiation measurements are not analysed here as an analysis of all solar radiation measurements in Iceland and a comparison to sunshine hours and cloud cover measurements is yet to be conducted, prior to looking at measurements from an isolated automatic station. The soil temperature measurements are done in two locations, one with limited vegetation and another where vegetation covers the ground. They are done at two depths, $5 \mathrm{~cm}$ and $15 \mathrm{~cm}$. The measurements

Table 1. Information on operational meteorological measurements in Surtsey as well as at the two other automatic stations in Vestmannaeyjar used in the study. The station number, where known, is shown in parenthesis.

\begin{tabular}{lllrl}
\hline & Period & Location & Height a.s.l. & Comments \\
\hline Surtsey & April-Sept 1967 & A few locations & - & Several interruptions \\
& April-Sept 1968 & A few location & - & Several interruptions \\
Surtsey (814) & $1969-1972$ & $63.3 \mathrm{~N} \mathrm{20.6 \textrm {W }}$ & $40 \mathrm{~m}$ & \\
Surtsey (6011) & Sept-Nov 1996 & $63.3 \mathrm{~N} \mathrm{20.6 \textrm {W }}$ & $154 \mathrm{~m}$ & On Austurbunki \\
Surtsey (6012) & $2009-$ & $63.2993 \mathrm{~N} 20.59947 \mathrm{~W}$ & $36 \mathrm{~m}$ & \\
Vestmannaeyjabær (6015) & $2002-$ & $63.43587 \mathrm{~N} 20.27578 \mathrm{~W}$ & $40 \mathrm{~m}$ & \\
Stórhöfði (6017) & $2004-$ & $63.39957 \mathrm{~N} 20.28825 \mathrm{~W}$ & $118 \mathrm{~m}$ & \\
\hline
\end{tabular}




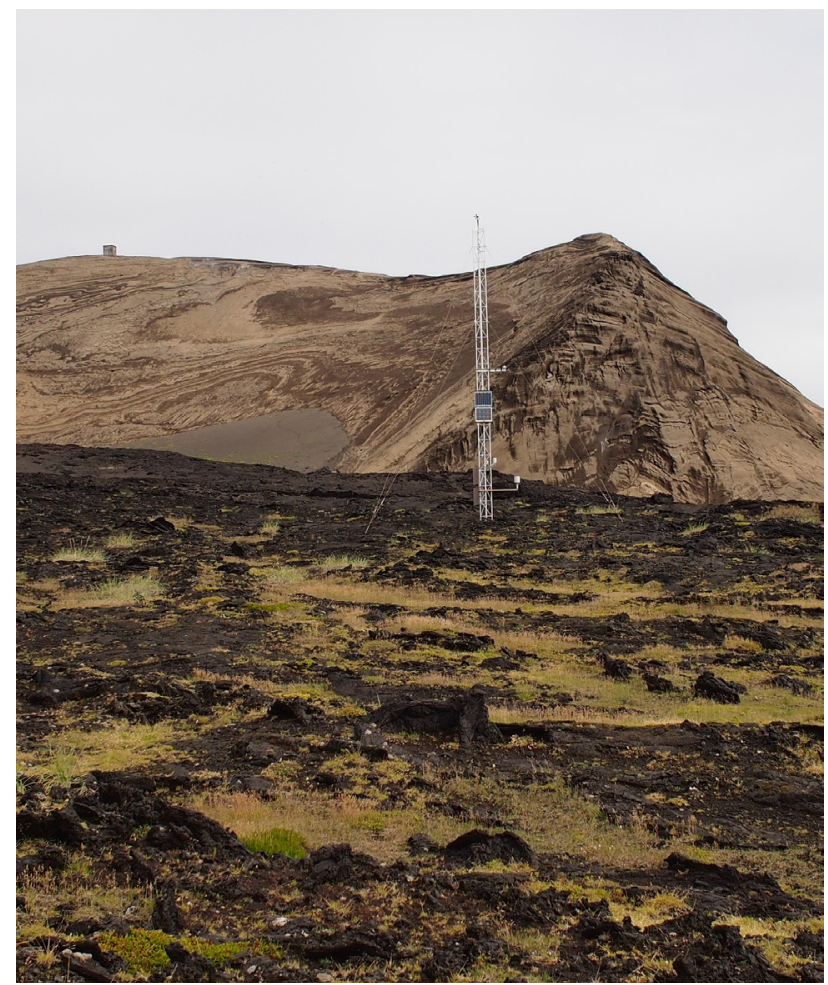

Figure 2. The automatic station in Surtsey (No. 6012) with Austurbunki in the background. Some previous measurements were conducted close to the shelter seen at the top of the fell. Photo: Vilhjálmur S. Porvaldsson, 17 July 2014.

are done in cooperation with the Surtsey Research Society. No attempts is made here to analyse these measurements. For information on the soil temperature measurements in Iceland see Petersen \& Berber (2018).

The stations in Stórhöfði (Station No. 6017) and Vestmannaeyjabær (Station No. 6015) measure

Table 2. The instrumentation of the automatic station in Surtsey.

\begin{tabular}{|c|c|c|}
\hline Parameter & Height & Instrument \\
\hline $\begin{array}{l}\text { Wind speed \& } \\
\text { direction }\end{array}$ & $10 \mathrm{~m}$ a.g.l. & Young wind monitor \\
\hline $\begin{array}{l}\text { Temperature \& } \\
\text { Humidity }\end{array}$ & $2 \mathrm{~m}$ a.g.l. & $\begin{array}{l}\text { Rotronic temperature } \\
\& \text { humidity probe }\end{array}$ \\
\hline Air pressure & $37.5 \mathrm{~m}$ a.s.1. & $\begin{array}{l}\text { Vaisala Barometric } \\
\text { pressure transmitter }\end{array}$ \\
\hline Precipitation & $1.5 \mathrm{~m}$ a.g.l. & $\begin{array}{l}\text { Lambrecht heated } \\
\text { tipping bucket }\end{array}$ \\
\hline Solar radiation & $5 \mathrm{~m}$ a.g.l. & Type unknown \\
\hline $\begin{array}{l}\text { Cloud conditions, } \\
\text { visibility \& surface } \\
\text { conditions }\end{array}$ & $3 \mathrm{~m}$ a.g.l. & Web camera \\
\hline Soil temperature & $\begin{array}{l}5 \text { and } 15 \mathrm{~cm} \text { depth } \\
\text { in an vegetated } \\
\text { and a sparsely } \\
\text { vegetated area. }\end{array}$ & Type unknown \\
\hline
\end{tabular}

the basic meteorological parameters. However, the automatic precipitation measurements in Stórhöfði have been unreliable and are thus not included here.

For this analysis, 10 year of data from Surtsey, Stórhöfði and Vestmannaeyjabær were obtained from the database of the Icelandic Meteorological Office (IMO), for the period 01.06.2009-31.05.2019. For most calculations daily values are used but for diurnal variation and frequency roses hourly data is used.

\section{RESULTS AND DISCUSSION}

\section{Annual variations}

Surtsey has a maritime climate, e.g. the annual temperature variation in Surtsey is dampened by the sea that cools the climate during summer and warms it during winter. Fig. 3, top panel, shows the annual variation of temperature as a boxplot. The graph is based on monthly values and $50 \%$ of the values for each calendar month are inside the box (25-75\% quantiles). The horizontal line inside each box is the median value, the whiskers (vertical lines) show outliers not further away from the box than $150 \%$ of its height. If there are outliers further away, they are depicted as points. The blue line represents monthly mean values. The figure shows a clear annual variability. December is the coldest month of the year with mean temperature of $3.2^{\circ} \mathrm{C}$ and August the warmest with $11.3^{\circ} \mathrm{C}$, resulting in an annual amplitude of $8.1^{\circ} \mathrm{C}$.

The monthly mean and median temperature in July and August are quite similar but there is more variability in July and outliers extend further away from the box. The same is true for January to March where the largest variation in temperature is seen in February. The temperature increases from spring into summer (April-July) with no overlapping of the boxes and decreases similarly from late summer to winter (August-December). In Iceland in general, July is the warmest month of the year and January the coldest, i.e. about a month after the sun is at its highest/lowest point in the sky (Einarsson, 1976). However, by the coast and on islands where the winds blow from the ocean the lag is often larger resulting in August being as warm or even warmer than July - as is true for Surtsey. Notice that this lag is not present during winter. In fact, December is in general colder than January. The reason for this is that during this century January-March have warmed more than other months of the year, in comparison to longer time periods, and December the least. This can be seen clearly in 

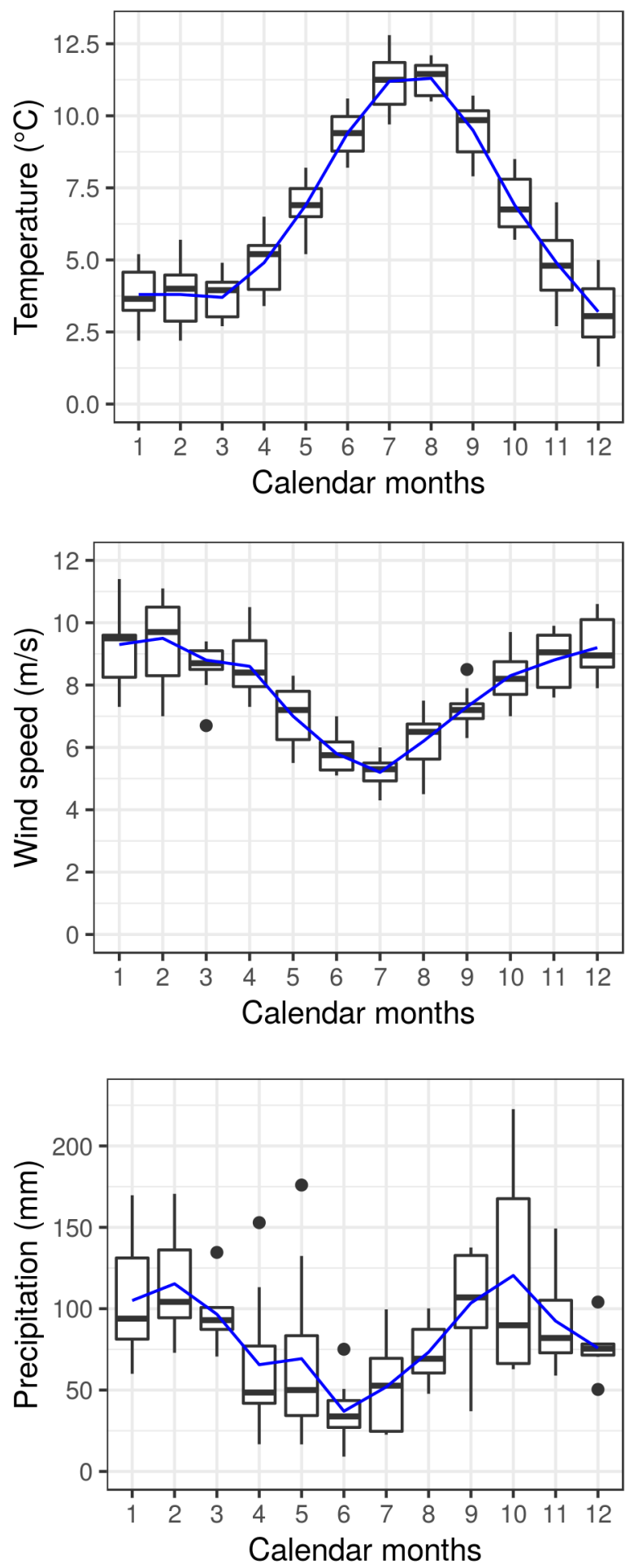

Figure 3. Annual variations of temperature $\left({ }^{\circ} \mathrm{C}\right.$, top), wind speed $(\mathrm{m} / \mathrm{s}$, centre) and precipitation ( $\mathrm{mm}$, bottom) in Surtsey 20092019. The boxes contain $50 \%$ of the data (25-75\% quantiles). The horizontal line is the median value and the whiskers show outliers within $150 \%$ of the height og the box. Outliers outside of that limit are shown with points. The blue line shows the monthly mean values.

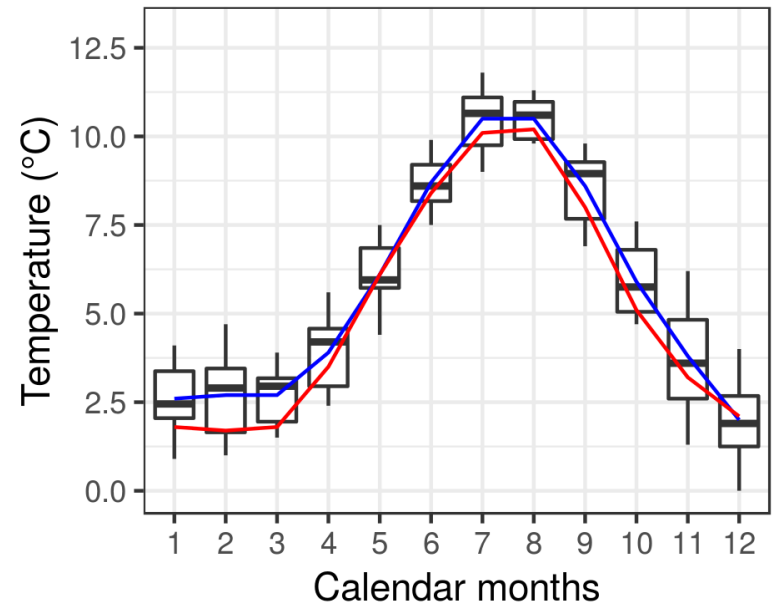

Figure 4. Annual temperature variations $\left({ }^{\circ} \mathrm{C}\right)$ in Stórhöfði 20092019. The boxes contain $50 \%$ of the data (25-75\% quantiles). The horizontal line is the median value and the whiskers show outliers within $150 \%$ of the height og the box. Outliers outside of that limit would be shown with points. The blue line shows the monthly mean values. The red line shows the monthly mean values for the 30-year period 1981-2010.

Fig. 4 that shows the annual temperature variations in Stórhöfði, for the applied period 2009-2019, with the monthly mean temperature for the 30 -year period 1981-2010 inset. Similar results are found for other coastal stations e.g. Reykjavík (not shown).

The annual wind speed variations are shown in the centre panel of Fig. 3. The highest monthly mean wind speed is found in February, but also the most variable monthly values, emphasising how variable the weather can be in this month. In general, wind speed variations are large in most months with least variations in March, June, July and September. As expected, the lowest monthly mean wind speed is in July.

The wind roses in Fig. 5 show the frequency of wind directions and wind speed for the whole period as well as for the summer months (June-August). Although Surtsey is about $32 \mathrm{~km}$ from the southern coast of mainland Iceland it is clear that the mainland has a large impact on the wind directions in Surtsey. On an annual basis the most frequent wind directions are easterly (east-northeasterly to east-southeasterly) as well as north-northeasterly. Westerly winds are common, along the coast of Iceland, but northerly and southerly less common. Most windstorms, where wind speed exceeds $20 \mathrm{~m} / \mathrm{s}$, are easterlies. Low pressure systems approaching Iceland from the south frequently result in strong southeasterly and easterly winds in this region. The glacier mountains 

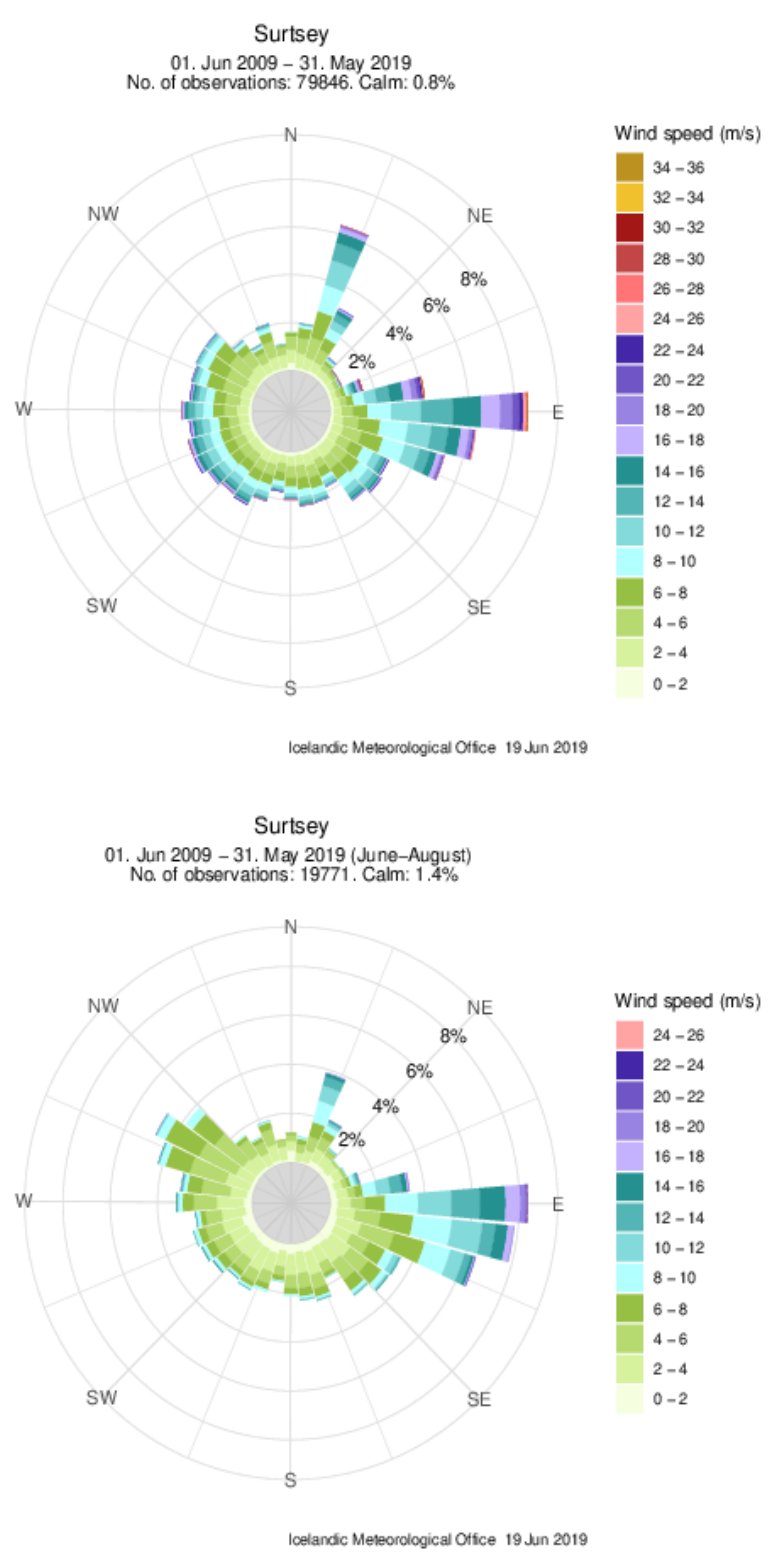

Figure 5. Wind roses showing the frequency of wind direction during (top) the whole year and (bottom) during June-August. The wind blows towards the centre of the wind rose. The colour show the wind speed. Hourly data from the time period 20092019.

at the southern tip of Iceland, Mýrdalsjökull and Eyjafjallajökull, can enhance these winds by forcing the air to flow on their south side and consequently increasing the easterly wind component. In addition, winds blow rarely from the northeast in Surtsey due to the same orographic features. The wind rose for the summer months shows a similar pattern but with increased west-northwesterly winds and decreased frequency of easterly winds as well as northnortheasterly winds. However, the strongest winds are still easterly.
The annual precipitation is shown in the bottom panel of Fig. 3. It is worth bearing in mind that precipitation measurements are challenging in Iceland. Firstly, there is an increasing undercatch of precipitation with increased wind speed. Pollock et al. (2018) estimate that at an exposed upland site the underestimation can be more than $23 \%$ on average. Secondly, solid precipitation is more difficult to catch than liquid precipitation due to the distortion of snowflake trajectories by the airflow around the gauges (e.g. Rasmussen et al., 2012). Heated rain gauges, such as the one in Surtsey, melt snow so that the amount catched can be measured although the precipitation intensity is in these cases not reliable. Given that Iceland is a windy country in general undercatch of precipitation is expected at most locations. However, as Surtsey is the southern point of Iceland, in maritime location and the station at low elevation winters are in general mild and solid precipitation can be expected to be much less common than liquid precipitation. Here, no attempt is made to correct for undercatch. In general the driest month of the year is June and the wettest months September and October as well as January and February during the winter. The largest variability is in October and least in December, although that may be due to undercatch of solid precipitation.

\section{Diurnal variations}

Due to limited solar radiation there is little diurnal variation of temperature during winter. Indeed, during December the mean temperature of each hour of the day is in the range $3 \cdot 1-3.3^{\circ} \mathrm{C}$. Also, the highest temperature can be at any time of the day as heat is transported into the region by synoptic systems pushing warm air masses northward. The lowest temperatures occur in calm conditions during winter darkness when long wave radiation results in heat loss from the surface and the surface then subsequently cools the adjacent air. The diurnal temperature variations in July in Surtsey and Vestmannaeyjabær are shown in Fig. 6. While the mean and median values are similar, the number of outliers differs greatly. The mean diurnal amplitude is $1.7^{\circ} \mathrm{C}$ and $2.3^{\circ} \mathrm{C}$ in Surtsey and Vestmannaeyjabær, respectively, with both lower minimum and higher maximum value at Vestmannaeyjabær. At both stations the lowest temperature is measured in early morning, at 4-5 UTC, and the highest temperature in the afternoon, at 15-16 UTC. However, while in Surtsey most outliers 


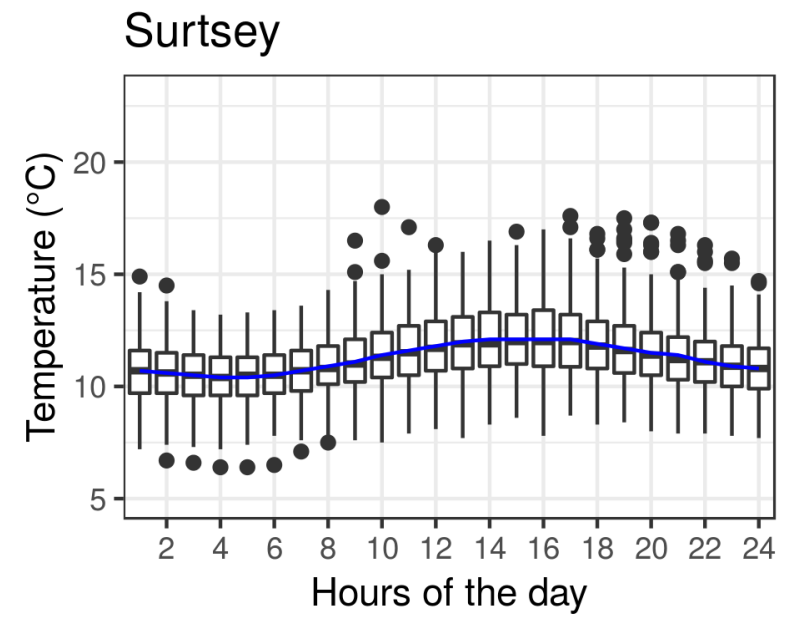

Vestmannaeyjabær

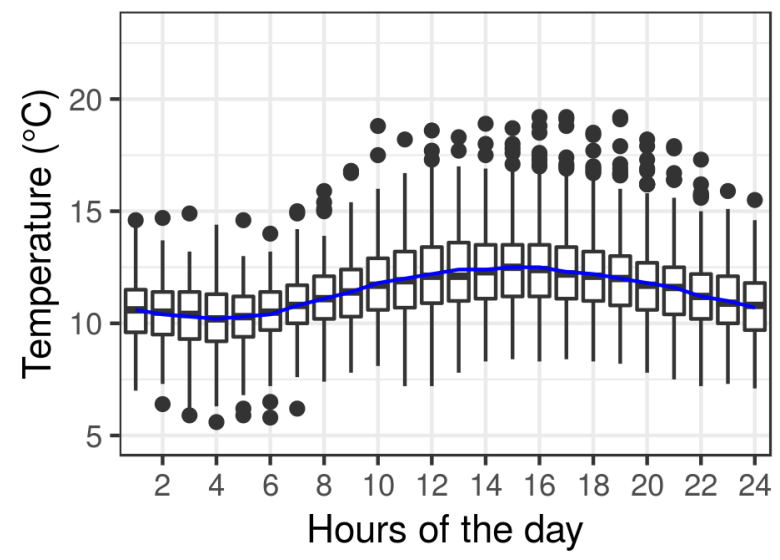

Figure 6. Diurnal variation of temperature $\left({ }^{\circ} \mathrm{C}\right)$ in Surtsey (top) and Vestmannaeyjabær (bottom) in July during the period 20092019.

lie within the maximum whiskers length $(150 \%$ of the height of the box), in Vestmannaeyjabær there is a considerable number of outliers that exceed these limits, especially with higher values during the day and evening. This suggests that the station Vestmannaeyjabær is less affected by the sea than the station in Surtsey, with the former located close to the centre of Heimaey and sheltered from the sea. For example, the highest hourly temperature measured in Surtsey is $18.0^{\circ} \mathrm{C}$ at $10 \mathrm{UTC}$ on 29 July 2018 when Vestmannaeyjabær measured $18.8^{\circ} \mathrm{C}$.

\section{Comparison of mean values and outliers}

Theannualmeanvalues for Surtsey, Vestmannaeyjabær and Stórhöfði are shown in Table 3 and maxima and minima in Table 4. Note that at Stórhöfði no data is retrieved from the manned station, only the automatic. Of these three stations Surtsey has the highest mean temperature, the fewest days where temperature falls
Table 3. Mean values during the period 2009-2019 at Surtsey, Vestmannaeyjabær and Stórhöfði.

\begin{tabular}{|c|c|c|c|}
\hline & Surtsey & $\begin{array}{l}\text { Vestmanna- } \\
\text { eyjabær }\end{array}$ & Stórhöfði \\
\hline Temperature & $6.6^{\circ} \mathrm{C}$ & $6.3^{\circ} \mathrm{C}$ & $5.7^{\circ} \mathrm{C}$ \\
\hline $\begin{array}{l}\text { Days with minimum } \\
\text { temperature below } \\
0^{\circ} \mathrm{C}\end{array}$ & 45 days & 66 days & 67 days \\
\hline $\begin{array}{l}\text { Days with maximum } \\
\text { temperature below } \\
0^{\circ} \mathrm{C}\end{array}$ & 2 days & 5 days & 7 days \\
\hline $\begin{array}{l}\text { Length of frost-free } \\
\text { period }\end{array}$ & 199 days & 175 days & 184 days \\
\hline Annual precipitation & $1009.3 \mathrm{~mm}$ & $1327.9 \mathrm{~mm}$ & - \\
\hline $\begin{array}{l}\text { Days with } \\
\text { precipitation }\end{array}$ & 229 days & 239 days & - \\
\hline Wind speed & $7.8 \mathrm{~m} / \mathrm{s}$ & $5.0 \mathrm{~m} / \mathrm{s}$ & $10.7 \mathrm{~m} / \mathrm{s}$ \\
\hline $\begin{array}{l}\text { Days with wind } \\
\text { speed exceeding } 20 \\
\mathrm{~m} / \mathrm{s}\end{array}$ & 30 days & 5 days & 120 days \\
\hline
\end{tabular}

below freezing level and fewest freezing days, i.e. where the temperature never exceeds freezing level. In addition, the station has on average the longest period of non-freezing temperatures, 199 days (approximately 6 months annually). The difference in elevation of Surtsey and Stórhöfði explains most

Table 4. Maxima and minima during the period 20092019 at Surtsey, Vestmannaeyjabær and Stórhöfði. If higher records exist at Vestmannaeyjabær and Stórhöfði outside of this period they are shown in parenthesis. Note that pressure measurements in Stórhöfði ended 9 June 2015 while the lowest pressure at the other stations is measured at the end of that year.

\begin{tabular}{llll}
\hline & Surtsey & $\begin{array}{l}\text { Vestmanna- } \\
\text { eyjabar }\end{array}$ & Stórhöfði \\
\hline $\begin{array}{l}\text { Maximum } \\
\text { temperature }\end{array}$ & $18.3^{\circ} \mathrm{C}$ & $\begin{array}{l}19.8^{\circ} \mathrm{C} \\
\left(23.6^{\circ} \mathrm{C}\right)\end{array}$ & $\begin{array}{l}18.4^{\circ} \mathrm{C} \\
\left(21.6^{\circ} \mathrm{C}\right)\end{array}$ \\
$\begin{array}{l}\text { Minimum } \\
\text { temperature }\end{array}$ & $-9.7^{\circ} \mathrm{C}$ & $\begin{array}{l}-10.6^{\circ} \mathrm{C} \\
-11.3^{\circ} \mathrm{C}\end{array}$ & \\
$\begin{array}{l}\text { Maximum wind } \\
\text { speed }\end{array}$ & $35.2 \mathrm{~m} / \mathrm{s}$ & $28.0 \mathrm{~m} / \mathrm{s}$ & $46.7 \mathrm{~m} / \mathrm{s}$ \\
$\begin{array}{l}\text { Maximum wind } \\
\text { gust }\end{array}$ & $47.8 \mathrm{~m} / \mathrm{s}$ & $45.8 \mathrm{~m} / \mathrm{s}$ & $56.6 \mathrm{~m} / \mathrm{s}$ \\
$\begin{array}{l}\text { Maximum annual } \\
\text { precipitation }\end{array}$ & $1071.8 \mathrm{~mm}$ & $1485.4 \mathrm{~mm}$ & - \\
$\begin{array}{l}\text { Maximum daily } \\
\text { precipitation }\end{array}$ & $67.5 \mathrm{~mm}$ & $85.6 \mathrm{~mm}$ & - \\
$\begin{array}{l}\text { Maximum hourly } \\
\text { precipitation }\end{array}$ & $13.8 \mathrm{~mm}$ & $16.8 \mathrm{~mm}$ & - \\
$\begin{array}{l}\text { Maximum sea level } \\
\text { pressure }\end{array}$ & 1041.6 & $1040.9 \mathrm{hPa}$ & $1038.4 \mathrm{hPa}$ \\
$\begin{array}{l}\text { Minimum sea level } \\
\text { pressure }\end{array}$ & 936.7 & $934.5 \mathrm{hPa}$ & $949.1 \mathrm{hPa}$ \\
$\begin{array}{l}\text { Minimum relative } \\
\text { humidity }\end{array}$ & $41 \% \mathrm{Ha}$ & $32 \%$ & $38 \%$ \\
\hline
\end{tabular}


of the difference in mean temperature between the stations, given the dry adiabatic lapse rate of $9.8^{\circ} \mathrm{C} /$ $\mathrm{km}$. However, it is also clear that the sheltering of Vestmannaeyjabær decreases slightly the impact of the sea on air temperature. This results in the period of non-freezing temperatures being on average 24 days shorter than in Surtsey and the days of freezing on average five but only two in Surtsey. The sheltering of Vestmannaeyjar is also clearly detected in the mean wind speed which is by far the lowest of the three stations and rarely exceeds $20 \mathrm{~m} / \mathrm{s}$. In comparison, at Stórhöfði the same limit is reached on average 120 days a year, or about one third of the year. On average it rains about $300 \mathrm{~mm}$ more in Vestmannaeyjabær than Surtsey as well as more frequently.

The maximum temperature measured during the period was $19.8^{\circ} \mathrm{C}$ in Vestmannaeyjabær and $18.3^{\circ} \mathrm{C}$ and $18.4^{\circ} \mathrm{C}$ in Surtsey and Stórhöfði, respectively. The lowest temperature measured at Surtsey was higher than at the two other station, or $-9.7^{\circ} \mathrm{C}$ compared to $-10.6^{\circ} \mathrm{C}$ at Vestamannaeyjabær and $-11.3^{\circ} \mathrm{C}$ at Stórhöfði. Again, this illustrates the impact of the sea as well as the low elevation in decreasing temperature variations. The maximum wind speed and wind gust where both measured at the windy Stórhöfði with considerably lower values at the other two stations. In particular, the maximum wind speed at Vestmannaeyjabær is low in comparison, only $28.0 \mathrm{~m} / \mathrm{s}$ while the values are $35.2 \mathrm{~m} / \mathrm{s}$ in Surtsey and $46.7 \mathrm{~m} / \mathrm{s}$ in Stórhöfði. For wind gust the highest measurement in Stórhöfði is $56.6 \mathrm{~m} / \mathrm{s}$ while at the other stations the maxima are $45.8 \mathrm{~m} / \mathrm{s}$ and $47.8 \mathrm{~m} / \mathrm{s}$, with the higher value at Surtsey.

Fig. 7 shows the monthly values of a few parameters for all stations. The variations in time are similar at all stations, as expected due to their proximity to each other. In general, the winter temperature is milder in Surtsey than at the other two stations, but summer temperature similar to the one in Vestmannaeyjabær. The wind speed lies within the values for the other
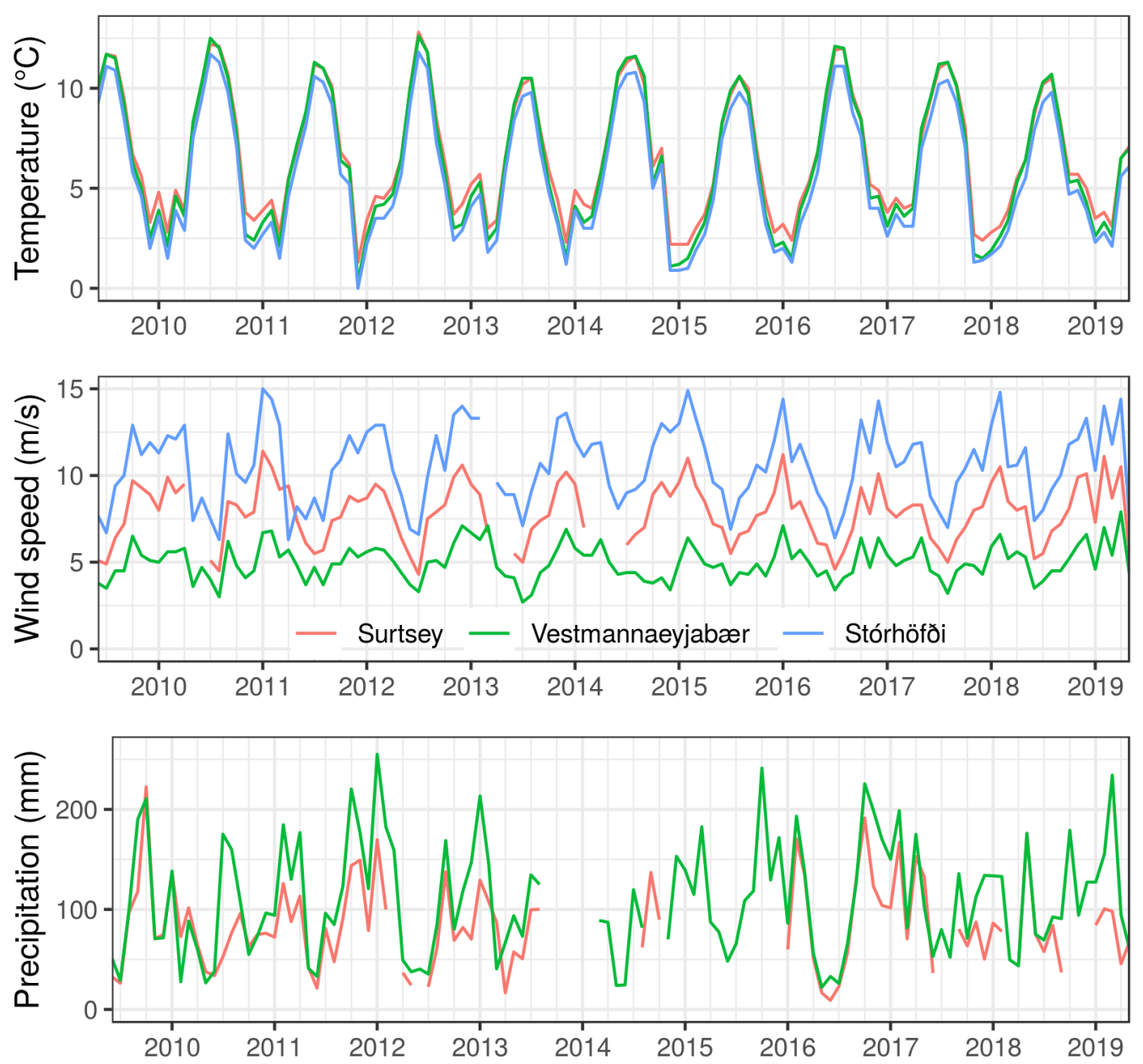

Figure 7. Monthly values of temperature $\left({ }^{\circ} \mathrm{C}\right.$, top), wind speed $(\mathrm{m} / \mathrm{s}$, centre) and precipitation (mm, bottom) at Surtsey, Vestmannaeyjabær and Stórhöfði, 2009-2019. 
stations; the sheltering of Vestmannaeyjabær is seen clearly as well as the wind enhancement at Stórhöfði. Precipitation is only measured at Surtsey and in Vestmannaeyjabær. Both time series have periods of missing data but there are indications that in general it rains more in Vestmannaeyjabær than in Surtsey and with higher intensity.

\section{CONCLUSION}

Surtsey is the southernmost part of Iceland. A weather station is on the island, located at $36 \mathrm{~m}$ a.s.l. and open to the sea. Measurements have been conducted continuously on the island since 2009 but the first routine measurments were conducted already in 1967. Here we inspect the time series June 2009May 2019.

Given the southerly location, the closeness to the sea and low elevation the station experiences a relatively mild but windy climate.

The monthly mean temperature is above freezing during all calendar months, December is the coldest month and August the warmest. A comparison with a 30 year time series, 1981-2010 at Stórhöfði, on Heimaey, shows that the last decade has seen warmer January-March months than earlier when these months were the coldest of the year.

The wind speed is rather high as the winds blow in from the sea and there is little surface friction to decrease the wind speed. The wind speed is in general between the one measured at Stórhöfoi and Vestmannaeyjabær, with both stations located in Heimaey, the largest island of the archipelago. At Stórhöfði the wind speed is considerably higher mainly due to the fact that the station is at the top of a hill that enhances the wind speed. On the other hand Vestmannaeyjabær is sheltered from the sea by the orography and the town itself. The wind directions in Surtsey are highly impacted by the mainland which can be seen clearly by the frequency of easterly winds as well as lack of northeasterly winds.

Precipitation measurements are in general challenging. A considerable undercatch can be expected in Surtsey, mainly because of the windy conditions. However, the pattern of summer months being the driest and winter months the wettest is consistent with expectations. The same is true for October being in general the wettest but also the most variable month, related to the prevalence of cyclones in the region.
The measurements show that the climate of Surtsey is similar to the climate at the other two stations in the Vestmannaeyjar archipelago with the largest difference being in wind speed.

This is the first time a comprehensive analysis of the climate in Surtsey has been done. It is the hope that this summary will be useful for anyone conducting research in Surtsey where weather plays a part as well as informative for those that have a general interest in Surtsey and its evolution.

\section{ACKNOWLEDGEMENT}

The authors would like to thank Ragnar Heiðar prastarson for producing the map of Surtsey and Vilhjálmur Smári Porvaldsson for the photo of the weather station. Thanks also to the weather measurement team at the Icelandic Meteorological Office for their contribution.

\section{REFERENCES}

Baldursson, S. \& Á. Ingadóttir (eds.) 2006. Nomination of Surtsey for the UNESCO World Heritage List. Icelandic Institute of Natural History, Reykjavík, 120 p.

Einarsson, M. Á. 1976. Veðurfar á Íslandi. Reykjavík: Iðunn.

Petersen, G. N. \& D. Berber 2018. Jarðvegsmælingar á Íslandi. Staða núverandi kerfis og framtíðarsýn. Icelandic Meteorological Office, VÍ 2018-009.

Pollock, M. D., G. O’Donnell, P. Quinn, M. Dutton, A. Black, M. E. Wilkinson, M. Colli, M. Stagnaro, L.G. Lanza, E. Lewis, C. G. Kilsby, \& P. E. O'Connell, 2018. Quantifying and mitigating wind-induced undercatch in rainfall measurements. WaterResources Research, 54 3863-3875.

https://doi.org/10.1029/2017WR022421

Rasmussen, R., B. Baker, J. Kochendorfer, T. Meyers, S. Landolt, A. P. Fischer, J. Black, J. M. Thériault, P. Kucera, D. Gochis, C. Smith, R. Nitu, M. Hall, K. Ikeda \& E. Gutmann, 2012: How Well Are We Measuring Snow: The NOAA/FAA/NCAR Winter Precipitation Test Bed. Bull. Amer. Meteor. Soc., 93, 811-829,

https://doi.org/10.1175/BAMS-D-11-00052.1

Sigtryggsson, H. 1968. Preliminary report on meteorological observations in Surtsey 1967. Surtsey Research Progress Report IV, 167-170.

Sigtryggsson, H. 1969. Preliminary report on the results of meteorological observations on Surtsey 1968. Surtsey Research Progress Report V, 119-120.

Surtseyjarfélagið 2007. Visited 30 July 2019 at surtsey.is. UNESCO 2008. Visited 30 July 2019 at unesco.org. 